\title{
Comparative Analysis of Off-grid Small Hydro-Solar PV- Diesel Hybrid System in South-west, Nigeria
}

\author{
W. Ajeba, B. Adebanji, and T. Fasina
}

\begin{abstract}
Reliable, efficient, and affordable power supply system is a necessary tool for rapid socio-economic development of any country. Power supply in Nigeria is grossly inadequate and inefficient. This work presented a comparison analysis of Off-Grid Small hydro-Solar Photovoltaic-Diesel Generator hybrid system in three selected locations in South-west, Nigeria. The selected locations are Molete (Oyo state), Abeokuta (Ogun state) and Ede (Osun state). The hydro data for the three locations were collected from their respective River Basin Development Authorities, while the solar data were obtained from National Aeronautics and Space Administration's global satellite database. The hybrid components consisting of Small hydropower (SHP), Solar Photovoltaic (PV), Battery (BB) and Diesel Generator (DG) were modelled and run using Hybrid Optimization Model for Electric Renewable software with the stream flow, the solar radiation, load and the system components costs as inputs. The work also carried out a comparative analysis based on economic parameters-return on investment and simple payback period different from the conventional use of net present cost, cost of energy (COE) and operating cost. The optimal hybrid combinations for these areas were compared with the usage of autonomous DG. The most optimal hybrid combination for Molete and Ede is PV-BB-SHP System with COEs of $\$ 0.347 / \mathrm{kWh}$ and $\$ 0.161 / \mathrm{kWh}$ respectively. The most optimal configuration for Abeokuta is PV-DG-BBSHP with COE of $\$ 0.290 / \mathrm{kWh}$. The results obtained (based on economic and technical considerations) showed that the hybrid system is viable for these areas. The outcome of the research will serve as guide for the government and prospective investors in formulating effective policies towards rapid development of renewable energy technologies in these areas.
\end{abstract}

Keywords - Economic Parameters, Environmental Impacts, Net Present Cost, Operating Cost, Payback Period.

\section{INTRODUCTION}

Reliable, efficient, and affordable power supply system is a necessary tool for rapid socio-economic development of any country [1], [2]. Even though, Nigeria is rich in oil, gas and coal for energy production, their use has never impacted positively on the Nigerian people [3]. Most of the essential needs like kerosene and gasoline are being sold at the rural areas at a very high price above the approved pump prices. The rural population, whose needs are often basic, therefore depends, to a large extent, on fuel wood as a major traditional source of fuel. Almost $80 \%$ of the people living in the rural areas are estimated to be relying on fuel wood for their energy needs [4], [5].

Submitted on September 04, 2021.

Published on October 08, 2021.

W. Ajeba, Ekiti State University, Ado-Ekiti, Nigeria.

(e-mail: fredajeba@yahoo.co.uk)
Power supply in Nigeria is grossly inadequate and inefficient [6].The country depends heavily on power generation from fossil fuel and large hydro power generation. It operates 25 grid-connected electric power plants with a total installed capacity of 12,522 MW [7]. Power generations through these sources are very costly and absolutely unsustainable along with accompanying negative environmental impacts. Presently power generation capacity is between 3,000 MW and $6000 \mathrm{MW}$ [7]. This is insufficient for the growing population and the corresponding increase in energy demand.

Globally, renewable energy is gaining attention as a better alternative to the use of fossil fuel for power generation because of its inherent advantages of cleanliness, absence of toxic emissions, affordability, and ubiquity [8]. Renewable energy is sustainable, inexhaustible and environment-benign. The country is abundantly blessed with renewable energy sources (RES) such as small hydro, solar radiations, biomass, wind etc. [5], [9].

Nigeria is estimated to have about $10,000 \mathrm{MW}$ of renewable energy sources for large hydropower and $734 \mathrm{MW}$ for Small hydropower (SHP) [10]. Wind energy has potential of 150,000 Tera Joules per year with an average wind speed of 2.0 to $4.0 \mathrm{~m} / \mathrm{s}$. Solar radiation is estimated at $3.5-7.0$ $\mathrm{kWh} / \mathrm{m}^{2}$ and biomass at 144 million tonnes per year [5], [11].

So much research carried out by different authors, have shown the feasibility of hybrid technologies as a better alternative source of power generation in order to reduce the negative environmental effects caused by fossil fuels. Some of the works have presented divergent opinions on the suitability of optimization software or methods in one particular location or the other. A lot of works has also been done on both off grid and grid connected hybrid system[3], [7], [12]-[16].

Ref. [17] assessed an off-grid hybrid configuration of solar photovoltaic (PV), wind (WD), battery bank (BB) and Diesel Generator (DG) for Malaysia rural electrification. The results of the study showed that PV-WD-BB is the most costeffective for all the villages considered. A comprehensive feasibility assessment of SHP-PV-DG-BB hybrid system was carried out for a rural village, Melkey Hera village in Ethiopia using HOMER software by [18]. SHP-PV-BB-DG hybrid system was found to be cost-effective, environment-friendly, and reliable.

Ref. [15] conducted a reliability assessment on a typical rural community in Nigeria for an off-grid PV-DG-BB hybrid

B. Adebanji, Ekiti State University, Ado-Ekiti, Nigeria.

(e-mail: bankole.adebanji@eksu.edu.ng)

T. Fasina, Ekiti State University, Ado-Ekiti, Nigeria.

(e-mail: emmanuel.fasina ${ }^{\circledR}$ eksu.edu.ng) 
system. The result showed that the hybrid system for the case study area is reliable and feasible. A techno-economic and comparative analysis of grid-connected PV-DG hybrid system for a remote village in India based on three different configurations was carried out by [16]. The three configurations are: grid-connected only, PV-grid and PV-DG based system. The result showed that PV-grid connected system is the most economical with the lowest net present cost (NPC).

A comparative study for six typical health clinics in offgrid hybrid modes were done by [14] across the six geopolitical zones of Nigeria. The hybrid system consists of PV, WD, DG and BB. It also considered the effect of subsidy removal by carrying out sensitivity analysis on the pump price. PV-DG-BB hybrid configuration was considered to be optimal for the regions.

Ref. [19] carried out a feasibility study of integrated hybrid system for an educational institution. The paper examined techno-economic validity of the hybrid system in on-grid and off-grid connected modes using HOMER software. The results of the study showed that grid-connected hybrid system is the optimal configuration to meet the power demand of the location in an effective and reliable manner. The gridconnected hybrid system is efficient, economical, and recorded a reduction in greenhouse gas emission.

Most of the researches reviewed used PV-DG with exclusion of small hydro resources. Very few works have been published in this area. This work did a comparative techno-economic analysis of SHP-PV-BB-DG hybrid system in three specific locations across the South-western part of Nigeria with its unique site characteristics. The work also carried out a comparative analysis based on economic parameters-return on investment and simple payback period different from the conventional use of net present cost, cost of energy (COE) and operating cost. The optimal hybrid combinations for these areas were compared with the usage of autonomous DG.

This work is divided into four sections. The first section is the introductory part while the second section was on the materials and methods used for the analysis. The results were presented and discussed in section three with conclusion and recommendations made in the fourth section.

\section{MATERIALS AND METHODS}

\section{A. Description of the Study Areas}

Southwest is one of the six geopolitical zones of Nigeria. It is considered as the largest political zone in Nigeria with land area of $77815 \mathrm{~km}^{2}$ comprising of the six states of Ekiti, Ondo, Lagos, Oyo, Ogun and Osun as in Fig. 1 [20].

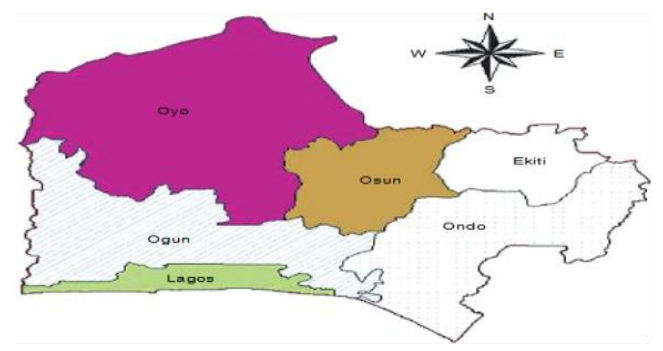

Fig. 1. Map of south-west states of Nigeria. Source: [21].

\section{B. Case Study 1: Molete (Oyo State)}

Molete lies at latitude $7.355^{\circ} \mathrm{N}$ and longitude $3.891^{\circ} \mathrm{E}$. The rainfall reaches its peak in June and September. The mean maximum temperature is $26.46^{\circ} \mathrm{C}$, minimum $21.426^{\circ} \mathrm{C}$ and the relative humidity is $74.55 \%$ [22]. This community has shops, markets, schools, hospital, barbing saloons, banks etc. The daily load profile is as in Fig. 2.

\section{Case Study 2: Abeokuta (Ogun State)}

Abeokuta lies at latitude $7.258^{\circ} \mathrm{N}$ and longitude $3.250^{\circ} \mathrm{E}$. Agriculture is the economic mainstay of the area. Some of the common industries in these areas are plastics, fruit canning, breweries, sawmills, aluminum, and food-processing factories. The daily load profile is as in Fig. 3.

\section{Daily Profile}

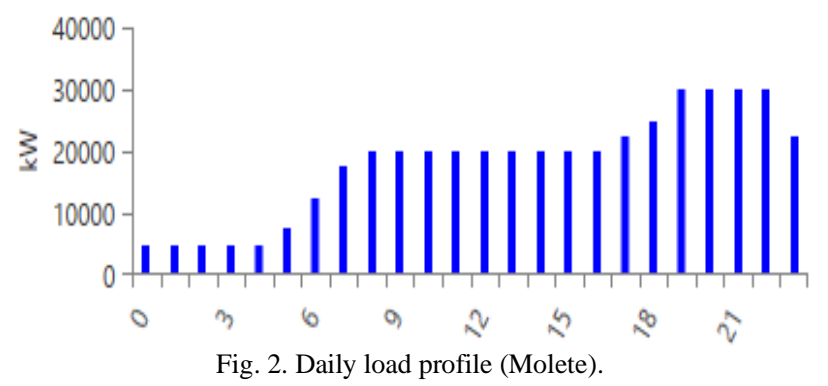

Daily Profile

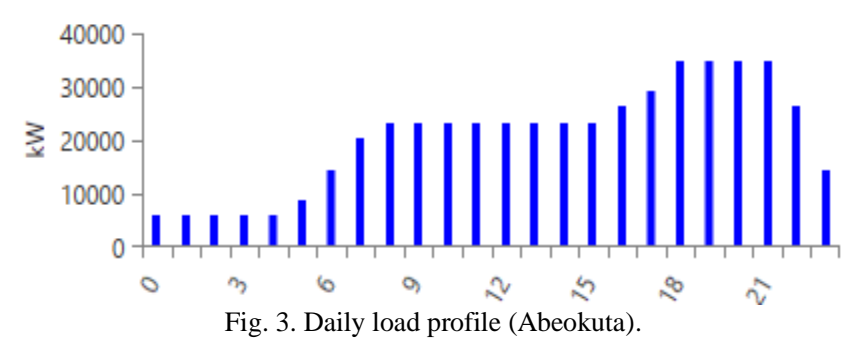

\section{Case Study 3: Ede (Osun State)}

It lies at Latitude $7.746^{\circ} \mathrm{N}$ and Longitude $4.438^{\circ} \mathrm{E}$. The rainfall reaches its peak in June and September. The people of Ede engage in farming, trading, and commercial activities on a large scale. The daily load profile is as in Fig. 4.

\section{Daily Profile}

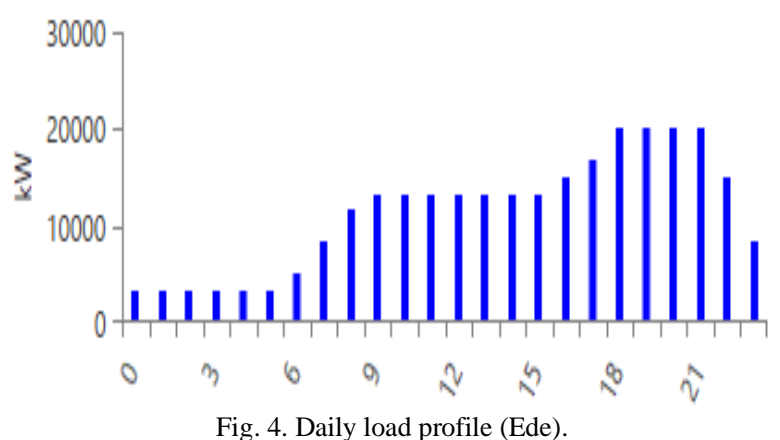

\section{RESEARCH APPROACH}

The load demand of the study areas (Molete, Abeokuta and Ede) was obtained from National Control Centre (NCC), Oshogbo and with the aid of questionnaires [23]. The hydro 
resource data of the areas such as stream flow and stream level were gathered from respective River Basin Development Authorities (RBDAs), covering ten years period [24]. This is as shown in Table 1. The daily solar radiation data and clearness indices of the study areas covering ten years period (2008-2018) were obtained from National Aeronautics and Space Administration's global satellite as in Table II [25].

The hybrid components consist of SHP, PV, BB and DG. The components were modelled and run using HOMER software with the stream flow, the solar radiation data, load, and the system components costs as inputs. The capital costs of all system components used for the study were based on quotes from component manufacturers and suppliers both in Nigeria and overseas. The hybrid component cost is as in Table 3. The results of the simulations were comparatively analyzed based on technical and economic considerations among the three selected locations. The three typical HOMER hybrid models for the study areas are as in Fig. 5, 6 and 7.

TABLE I: Monthly AVERAge Hydro Data of THE StUdy AREAS

\begin{tabular}{|c|c|c|c|c|c|c|}
\hline \multirow[b]{2}{*}{ Month } & \multicolumn{2}{|c|}{ Ogunpa river } & \multicolumn{2}{|c|}{ Oyan river } & \multicolumn{2}{|c|}{ Osun river } \\
\hline & Head (m) & $\begin{array}{c}\text { Stream } \\
\text { flow }(\mathrm{L} / \mathrm{s})\end{array}$ & Head (m) & $\begin{array}{c}\text { Stream } \\
\text { flow }(\mathrm{L} / \mathrm{s})\end{array}$ & Head (m) & $\begin{array}{c}\text { Stream flow } \\
(\mathrm{L} / \mathrm{s})\end{array}$ \\
\hline January & 0.5 & 270 & 0.28 & 410 & 1.63 & 16980 \\
\hline February & 0.52 & 260 & 0.25 & 360 & 1.6 & 16090 \\
\hline March & 0.51 & 340 & 0.33 & 530 & 1.61 & 16190 \\
\hline April & 0.7 & 610 & 0.69 & 1350 & 1.66 & 16640 \\
\hline May & 0.72 & 1460 & 1.1 & 4890 & 1.85 & 18490 \\
\hline June & 0.63 & 2880 & 1.62 & 7980 & 2.29 & 26850 \\
\hline July & 0.72 & 3410 & 2.44 & 12730 & 2.54 & 36660 \\
\hline August & 1.09 & 2570 & 2.93 & 14630 & 2.7 & 40600 \\
\hline September & 0.77 & 2430 & 2.33 & 12210 & 3.02 & 48930 \\
\hline October & 0.65 & 1630 & 1.77 & 7750 & 3.13 & 50990 \\
\hline November & 0.49 & 910 & 1.07 & 3070 & 2.59 & 24860 \\
\hline December & 0.39 & 390 & 0.36 & 540 & 1.84 & 18200 \\
\hline Annual average & 0.64 & 1430 & 1.26 & 5537.5 & 2.205 & 27623.333 \\
\hline
\end{tabular}

TABLE II: MONTHLy AVERAGE SOlaR DATA OF THE STUDY AREAS

\begin{tabular}{|c|c|c|c|c|c|}
\hline \multicolumn{2}{|c|}{ Molete Solar Data } & \multicolumn{2}{|c|}{ Abeokuta Solar Data } & \multicolumn{2}{|c|}{ Ede Solar Data } \\
\hline $\begin{array}{l}\text { Solar Irradiation } \\
\left(\mathrm{kWh} / \mathrm{m}^{2}\right)\end{array}$ & Clearness Index & $\begin{array}{c}\text { Solar Irradiation } \\
\left(\mathrm{kWh} / \mathrm{m}^{2}\right)\end{array}$ & Clearness Index & $\begin{array}{c}\text { Solar Irradiation } \\
\left(\mathrm{kWh} / \mathrm{m}^{2}\right)\end{array}$ & Clearness Index \\
\hline 5.28 & 0.525 & 5.28 & 0.525 & 5.32 & 0.529 \\
\hline 5.29 & 0.503 & 5.29 & 0.503 & 5.44 & 0.518 \\
\hline 5.32 & 0.521 & 5.32 & 0.521 & 5.28 & 0.517 \\
\hline 5 & 0.518 & 5 & 0.518 & 4.92 & 0.51 \\
\hline 3.6 & 0.363 & 3.6 & 0.363 & 3.43 & 0.346 \\
\hline 4.3 & 0.416 & 4.3 & 0.416 & 4.26 & 0.412 \\
\hline 4.91 & 0.474 & 4.91 & 0.474 & 4.85 & 0.468 \\
\hline 5.31 & 0.526 & 5.31 & 0.526 & 5.35 & 0.53 \\
\hline 5.27 & 0.532 & 5.27 & 0.532 & 5.35 & 0.54 \\
\hline
\end{tabular}

TABLE III: COSTS OF HYBRID SYSTEM COMPONENTS

\begin{tabular}{|c|c|c|c|c|}
\hline Components & Price & $\begin{array}{c}\text { Initial } \\
\text { costs }(\$)\end{array}$ & $\begin{array}{l}\text { Replacement } \\
\text { costs }(\$)\end{array}$ & $\begin{array}{c}\mathrm{O} \& \mathrm{M} \\
\text { costs }(\$)\end{array}$ \\
\hline Hydro turbine & $\begin{array}{l}\$ / \mathrm{kW} \text { of } \\
\text { capacity }\end{array}$ & 600 & 480 & 12 \\
\hline PV module & $\begin{array}{l}\$ / \mathrm{kW} \text { of } \\
\text { capacity }\end{array}$ & 2,000 & 1600 & 24 \\
\hline $\begin{array}{c}\text { Diesel } \\
\text { generator }\end{array}$ & $\begin{array}{l}\$ / \mathrm{kW} \text { of } \\
\text { capacity }\end{array}$ & 400 & 320 & 8 \\
\hline Converter & $\begin{array}{l}\$ / \mathrm{kW} \text { of } \\
\text { capacity }\end{array}$ & 360 & 288 & 4.32 \\
\hline Battery & 1 qty & 300 & 240 & 3.6 \\
\hline
\end{tabular}

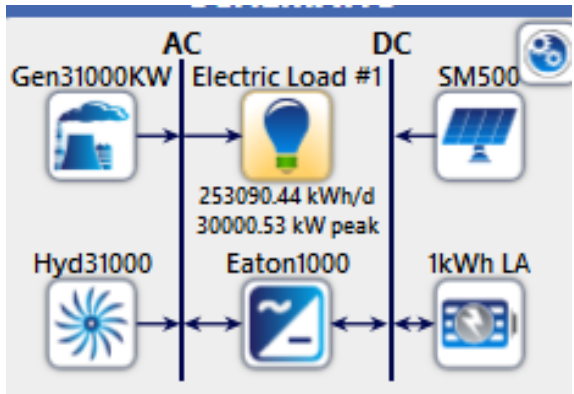

Fig. 5. Typical HOMER hybrid model for Molete.

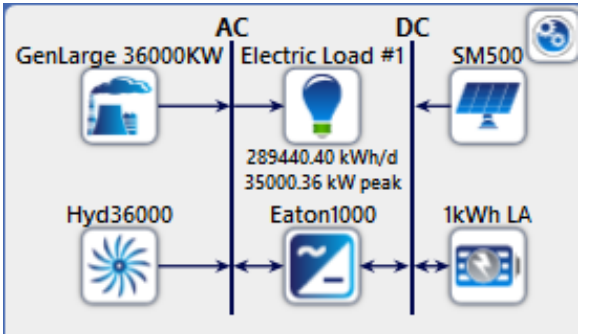

Fig. 6. Typical HOMER hybrid modelfor Abeokuta.

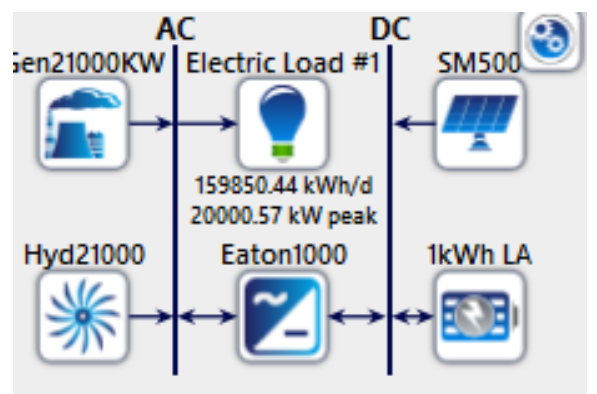

Fig. 7. Typical HOMER hybrid model for Ede 
The total hybrid power generated at any time $t$, is given as in equation 1 [26].

$P(t)=\sum_{S H P=1}^{N_{H}} P_{S H P}+\sum_{P V=1}^{N_{P}} P_{P V}+\sum_{D G=1}^{N_{D}} P_{D G}$

where:

$\mathrm{N}_{\mathrm{H}}$ is the number of small-hydro generator units;

$\mathrm{N}_{P}$ is the number of PV cell units;

$\mathrm{N}_{D}$ is the number of diesel generator units.

The total capital cost $\mathrm{C}_{\mathrm{C}}$ for the hybrid system is as in equation 2 [26].

$C_{C}=\sum_{S H P=1}^{N_{H}} C_{S H P}+\sum_{P V-1}^{N_{P}} C_{P V G}+\sum_{D G-1}^{N_{D}} C_{D G}+$ $\sum_{B-1}^{N_{B}} C_{B B}+C_{F}$

where:

$\mathrm{C}_{\mathrm{F}}$ is fixed cost including cost of converter and other installation cost.

The annual operating cost $(\mathrm{Co})$ computed based on the operating costs of all the installed units for the interval $t$ in a day is as shown by (3):

$$
\begin{aligned}
& \sum_{\mathrm{t}=1}^{365}\left\{\sum _ { t = 1 } ^ { 2 4 } \left(\mathrm{C}_{\mathrm{OSHP}}(\mathrm{t})+\mathrm{C}_{\mathrm{OPV}}(\mathrm{t})+\mathrm{C}_{\mathrm{ODG}}(\mathrm{t})+\mathrm{C}_{\mathrm{OBB}}(\mathrm{t})+\right.\right. \\
& \left.\left.\mathrm{C}_{\mathrm{OF}}(\mathrm{t})\right)\right\}
\end{aligned}
$$

comprises both capital and operating cost and is as in (4):

$$
\mathrm{C}_{\text {annual }}=\left(\mathrm{C}_{\mathrm{c}} \cdot \mathrm{CRF}+\mathrm{C}_{\mathrm{O}}\right)
$$

where:

$C_{C}$ is the capital cost;

$C_{O}$ is the operating cost;

$\mathrm{CRF}$ is Capital recovery factor for the system with expected discount rate.

The unit cost of electricity generated by hybrid energy system is as in (5).

$$
\mathrm{COE}=\frac{\mathrm{C}_{\text {annual }}}{\mathrm{E}_{\mathrm{T}}}
$$

where:

$E_{T}$ is the total load served in $\mathrm{kWh} /$ year.

\section{A. Mathematical Model of Small-hydro Generator}

The electrical power generated by small hydropower generator is as in (6) [26].

$$
P_{S H P}(t)=\eta_{H y d r o} \frac{9.81 \times Q \times \rho_{\text {water }} \times h}{1000}
$$

and the total energy in $\mathrm{kWh}$ is as in (7):

$$
E_{S H P}(t)=P_{S H P}(t) \times t
$$

where:

$P_{S H P}(t)$ is the electrical power generated by small hydropower generator;

$\eta_{\text {Hydro }}$ is the hydro efficiency;

$\mathrm{Q}$ is the discharge in $\mathrm{m}^{3} / \mathrm{s}$;

$P_{\text {water }}$ is the density of water; $h$ is the falling height head(m);

$E_{S H P}(t)$ is the electrical energy generated by Small hydropower generator;

$t$ is the time in hour.

\section{B. Mathematical Model of PV Generator}

Using the solar radiation available, the hourly energy output of the PV generator $\left(E_{P V}\right)$ can be calculated according to $(8)[26]$.

$$
E_{P V}=G(t) \times A \times P \times \eta_{P V G}
$$

where:

$G(t)$ is the hourly irradiance in $\mathrm{kWh} / \mathrm{m}^{2}$;

$A$ is the surface area in $\mathrm{m}^{2}$;

$P$ is the PV penetration level factor;

$\eta_{P V G}$ is the PV generator efficiency.

The temperature effect (on PV cells) is ignored.

\section{Mathematical Model of Diesel Generator}

The hourly energy generated by diesel generator, $E_{D G}$ with rated power output, $E_{D G}$ is as expressed in (9) [26]:

$$
E_{D G}(t)=P_{D G}(t) \times \eta_{D G}
$$

where:

$\eta_{D G}$ is the diesel generator efficiency.

For better performance and higher efficiency, the DG will always operate between $80 \%$ and $100 \%$ of their $\mathrm{kW}$ rating. A linear model was assumed for the fuel consumption rate, $\mathrm{F}$, in litres/hour of operation by the DG [27] as expressed in (10).

$F=\left(0.246 \times P_{\text {out }}\right)+\left(0.08415 \times P_{\text {Ngen }}\right)$ litres/hour $(10)$

where:

$P_{\text {out }}$ is the operating output power in $(\mathrm{kW})$;

$P_{N g e n}$ is the rated power of DG $(\mathrm{kW})$.

The fuel cost, $C_{\text {fuel }}$ is calculated as in (11):

$$
C_{\text {fuel }}=C_{\text {diesel }} \mathrm{F}\left(R_{S}\right)
$$

where:

$C_{\text {diesel }}$ is fuel price per litre;

$\mathrm{F}\left(R_{S}\right)$ is fuel consumption rate.

\section{RESUlTS AND DisCUSSION}

The section is broadly divided into three subsections: economic parameter analysis, comparison analysis of the optimal hybrid system with autonomous DG and Greenhouse gas emission consideration. These are subsequently discussed in the following subsections.

\section{A. Economic Parameter Consideration}

The optimal combination for Moleteis PV-BB-SHP hybrid system. Therenewable resource fraction (RF) is $100 \%$. The total portion of energy production is from renewable energy, which implies a completely clean hybrid power system. The optimal combination for Abeokuta is PV-DG-BB-SHP system. The RF is $99.9 \%$, which means minimal DG penetration. The optimal combination for Ede is PV-BB-SHP 
system and the RF is $100 \%$. The economic parameter comparison is based on net present cost ((NPC),cost of energy (COE),return on investment (R.O.I) and simple payback period (SPP).

\section{B. Net Present Cost (NPC)}

NPC can be described as the present costs of the system over its lifetime without the present values of the revenue generated over its lifetime. It is one of the most common indices being used in determining optimal selection of any hybrid system. The NPC for the selected hybrid topology for Molete, Abeokuta and Ede are presented as in Fig. 8.

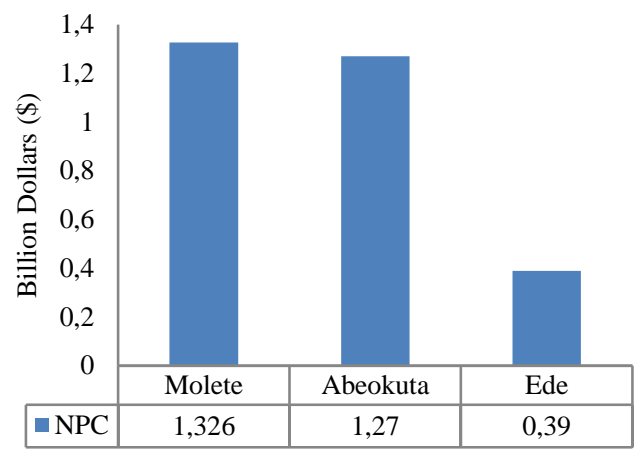

Fig. 8. Comparative NPC chart for the study areas.

\section{Cost of Energy (COE)}

The cost of energy (COE) is the average cost per kWh of useful electrical energy produced by the system. This was prioritized in determining the optimal configuration for the areas, as high COE may not be affordable to the communities. The COE of the winning hybrid architecture for the three locations is as in Fig. 9. The COE of the three communities varies slightly.

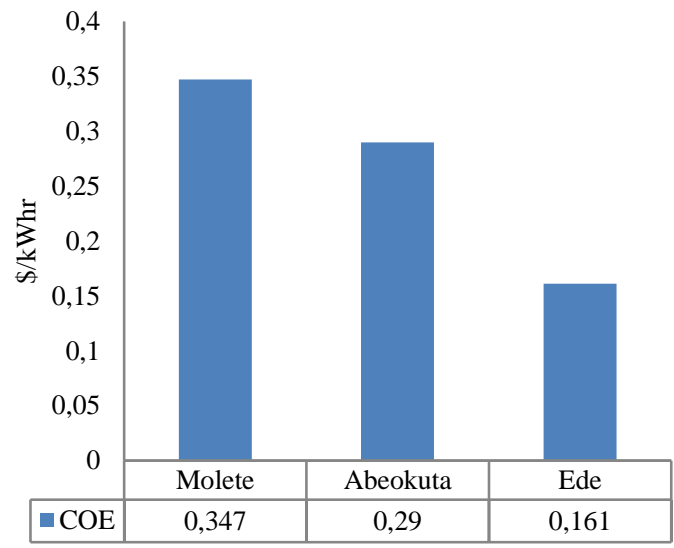

Fig. 9. Comparative COE chart for the study areas.

\section{Return on Investment (ROI) and Simple Payback} Period (SPP)

The prospect of return on investment (R.O.I) and simple payback year are catalysts for investment in hybrid power projects. A positive R.O.I means that net returns exceed total costs. A negative R.O.I means that total costs exceed total returns (this investment produces a loss). PV-BB-SHP hybrid system for Molete has a positive R.O.I of $75.1 \%$ and simple payback period (SPP) of 9.5 years. It means investment in this project break even in 9.5 years. This shows that the hybrid project is profitable.

The R.O.I. for Abeokuta (PV-DG-BB-SHP) is positive, so are other metrics which means a favourable comparison. In the same vein, the winning hybrid architecture (PV-BB-SHP) for Ede area, showed a positive correlation. The R.O.I. of the off-grid hybrid system is positive, so are other indices giving favourable comparison also. This is as shown in Fig. 10 and 11.

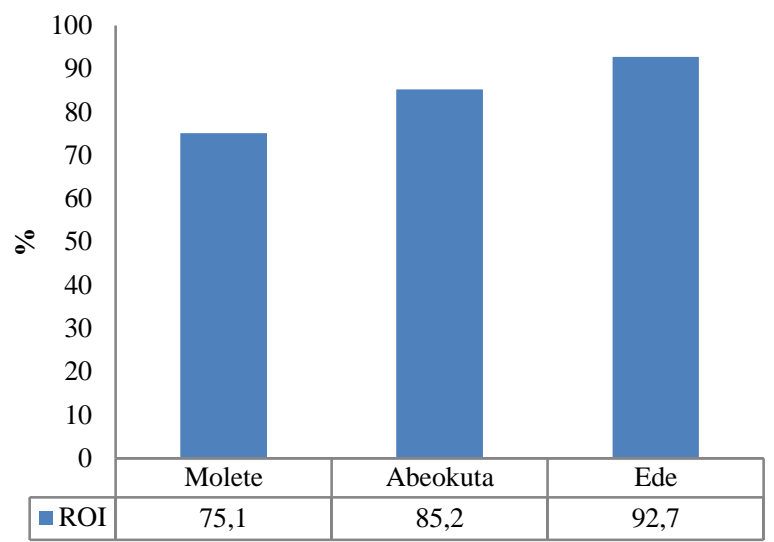

Fig. 10. Comparative R.O.I. chart for the study areas.

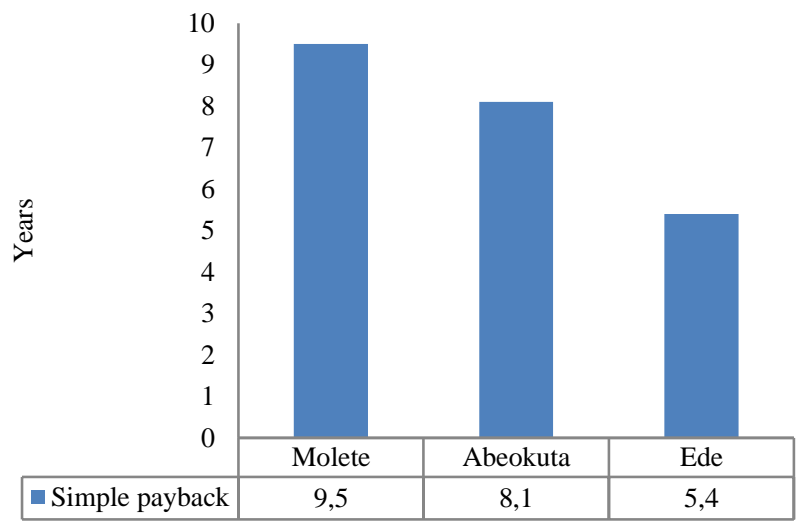

Fig. 11. Comparative SPP chart for the study areas

\section{OPTIMAL HYBRID COMPARISON WITH AUTONOMOUS DG}

Comparative economic analysis between the optimal hybrid selections for the study areas and an autonomous diesel generator capable of meeting the load requirement of the areas was done. This comparison is as presented in Table IV. In Molete, for instance, the initial capital cost of using an autonomous DG is $\$ 13.6$ million, with COE of $\$ 26.03 / \mathrm{kWh}$. The DG consumes 29,185,922 litres of diesel annually corresponding to $\$ 18.36$ million. The NPC and the COE is on the high side for the DG though, the investment cost is low when compared to the hybrid system. This ultimately justifies preference for this hybrid power system aside from the environmental degradation concern as a result of toxic emissions from DG.

A comparative analysis chart of the C.O.E of the optimal hybrid configuration with autonomous DG usage is as shown in Fig. 12. The C.O.E of the DG option for the areas is extremely high and unaffordable compared to the Hybrid systems; hence the hybrid systems present better option for implementation. 
TABLE IV: COMPARATIVE ANALYSIS OF THE ECONOMIC PARAMETERS OF OPTIMAL HYBRID SYSTEM WITH AN AUTONOMOUS DG

\begin{tabular}{|c|c|c|c|c|c|c|}
\hline \multirow{2}{*}{$\begin{array}{c}\text { Study Areas } \\
\text { System configuration }\end{array}$} & \multicolumn{2}{|c|}{ Molete } & \multicolumn{2}{|c|}{ Abeokuta } & \multicolumn{2}{|c|}{ Ede } \\
\hline & PV-BB-SHP & DG & $\begin{array}{l}\text { PV-DG-BB- } \\
\text { SHP }\end{array}$ & DG & PV-BB-SHP & DG \\
\hline Initial capital cost $(\$)$ & 643 million & 13.6 million & 578 million & 14.0 million & 170 million & 9.2 million \\
\hline Net present cost $(\$)$ & 1.32 billion & 99.5 billion & 1.27 billion & 103 billion & 390 million & 67.4 billion \\
\hline L. C. O. E (\$) & $0.347 / \mathrm{kWh}$ & $26.03 / \mathrm{kWh}$ & $0.290 / \mathrm{kWh}$ & $23.45 / \mathrm{kWh}$ & $0.161 / \mathrm{kWh}$ & $27.9 / \mathrm{kWh}$ \\
\hline Operating cost $(\$)$ & 16.5 million & 2.40 billion & 16.6 million & 2.48 billion & 5.31 million & 1.63 billion \\
\hline Generator hours of operation(hrs) & 0 & 8,760 & 30 & 8,760 & 0 & 8,760 \\
\hline Fuel consumption per annual (L) & 0 & $29,185,922$ & 15,480 & $32,986,508$ & 0 & $19,190,616$ \\
\hline Cost of fuel/annual (\$0.629/L) & 0 & 18.36 million & 9.74 million & 20.75 million & 0 & 12.07 million \\
\hline
\end{tabular}

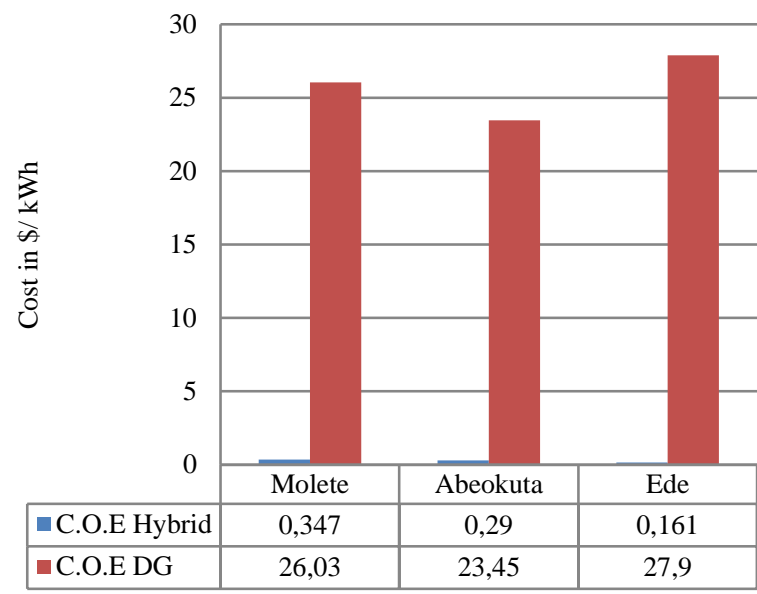

Fig. 12. Comparative analysis of hybrid system COE swith DG.

\section{GREENHOUSE GAS EMISSION CONSIDERATION}

The choice of hybrid power system as the best power option can be better appreciated when compared with an autonomous DG presented as energy option for these communities in terms of pollution. The list of pollutants emitted by using the DG alone in comparison with the optimal hybrid selection for the areas is as in Table $\mathrm{V}$. The winning hybrid architecture selected in place of an autonomous with the same capacity for power generation for the three study areas prevented the emission of these pollutants, the RF being $100 \%$ except for Abeokuta area whose RF is $99.9 \%$.

In Molete, the DG consumes 29,185,922 litres of fuel per annum, with emission of 76,397,504 $\mathrm{kg}$ of $\mathrm{CO}_{2}, 481,568 \mathrm{~kg}$ of carbon monoxide per annum and other toxic gases to the environment. The DG is assumed to operate for8760 hours annually.

In Abeokuta, there is about $99.95 \%$ decrease in both $\mathrm{CO}_{2}$ and $\mathrm{CO}$ emissions followed by drastic percentage reductions in other toxic pollutants. It can be seen from Table 4 that the number of hours of run of the DG when operated in a hybrid system is 30 hours/year compared to an autonomous DG whose operation hours is 8760 hours/year resulting in saving of 32,971,028 litres of fuel per annum. The optimal combination for Ede (PV-BB-SHP System) results in diesel fuel consumption saving of 19,190,616 litres per annum.The more the renewable resources available in the hybrid power system, the more the percentage reduction in emissions.

These developments impact positively on the environment in prevention of global warming, cancer or mutations, depletion of ozone layer and problem of acidification. A comparative chart of pollutant emission between the optimal hybrid system and autonomous DG is shown in Fig. 13. Molete and Ede have hybrid configuration with $100 \%$ R.F while Abeokuta hybrid system has $99.9 \% \mathrm{RF}$ and insignificant emissions.

\section{CONCLUSION}

This work presented a techno-economic analysis of off-grid Small hydro-Solar Photovoltaic-Diesel Generator hybrid system for three selected locations in the South-western part of Nigeria. The most optimal hybrid combination for Molete and Ede is PV-BB-SHP System with COE of $\$ 0.347 / \mathrm{kWh}$ and $\$ 0.161 / \mathrm{kWh}$ respectively. The most optimal configuration for Abeokuta is PV-DG-BB-SHP with COE of $\$ 0.290 / \mathrm{kWh}$.

A comparative analysis based on economic parametersreturn on investment and simple payback period, different from the conventional use of net present cost, cost of energy and operating cost was carried out. The results obtained (based on economic and technical considerations) showed that the hybrid system is viable for these areas.

The work also compared the optimal configuration for each selected case study with an autonomous Diesel Generator as power generation model for meeting the energy need of the areas. The outcome of this work will assist governments and investors in formulating effective policies towards rapid development of renewable energy technologies in these areas.

\section{ACKNOWLEDGMENT}

We acknowledge our indebtedness and deepest sense of gratitude to all members of staff, Faculty of Engineering, Ekiti State University, Nigeria.

TABLE V: EMISSIONS FROM THE HYBRID SYSTEMS COMPARED WITH A DG FOR THE AREAS

\begin{tabular}{|c|c|c|c|c|c|c|}
\hline \multirow{2}{*}{$\begin{array}{c}\text { Study Areas } \\
\text { System configuration }\end{array}$} & \multicolumn{2}{|c|}{ Molete } & \multicolumn{2}{|c|}{ Abeokuta } & \multicolumn{2}{|c|}{ Ede } \\
\hline & PV-BB-SHP & DG & PV-DG-BB-SHP & DG & PV-BB-SHP & DG \\
\hline Carbon dioxide emission (kg/yr) & 0 & $76,397,504$ & 40,592 & $86,498,063$ & 0 & $50,233,641$ \\
\hline Carbon monoxide emission $(\mathrm{kg} / \mathrm{yr})$ & 0 & 481,568 & 210 & 447,495 & 0 & 316,645 \\
\hline Unburned hydrocarbons emission ( $\mathrm{kg} / \mathrm{yr})$ & 0 & 21,014 & 11.1 & 23,750 & 0 & 13,817 \\
\hline Particulate matter emission (kg/yr) & 0 & 2,919 & 1.8 & 3,826 & 0 & 1,919 \\
\hline Sulfur dioxide emission $(\mathrm{kg} / \mathrm{yr}$ & 0 & 187,079 & 99.2 & 211,441 & 0 & 123,010 \\
\hline Nitrogen oxides emission (kg/yr) & 0 & 85,765 & 40.2 & 85,765 & 0 & 297,455 \\
\hline
\end{tabular}




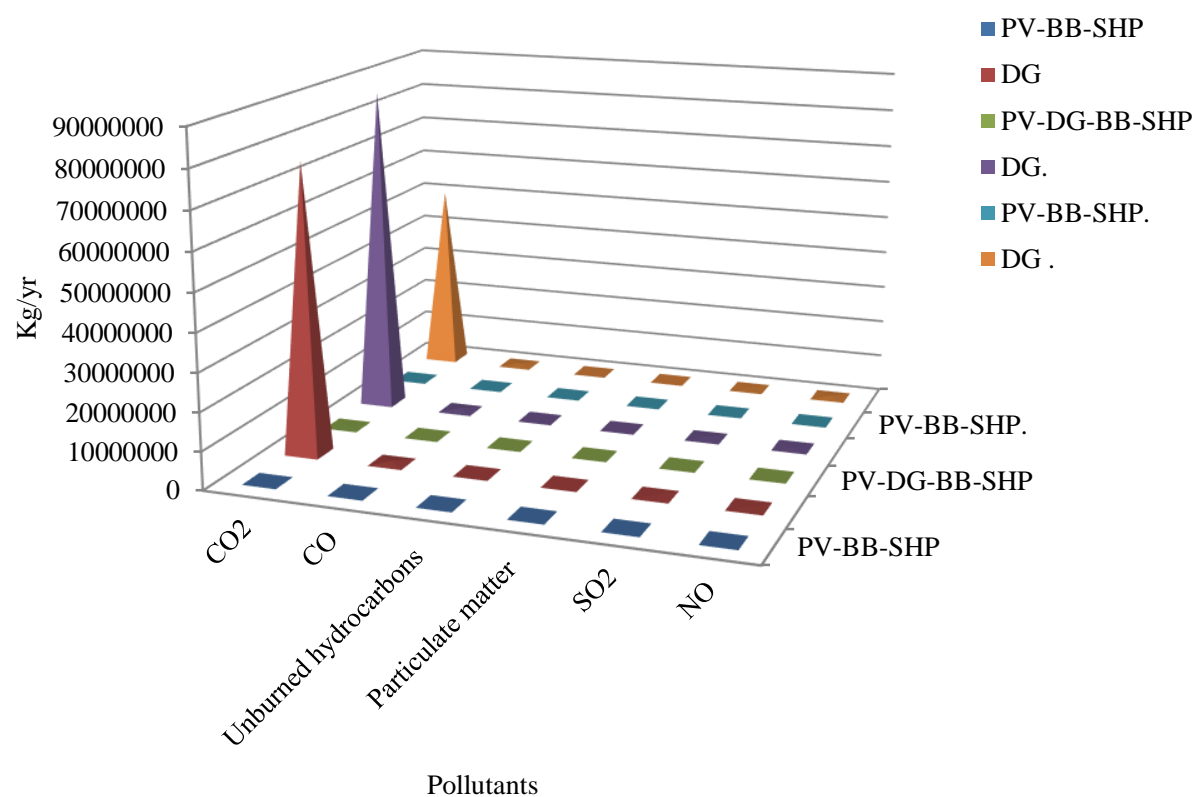

Fig. 13. Comparative chart of emissions between the optimal hybrid systems and autonomous DG.

\section{REFERENCES}

[1] A. Ram, T. Saurabh, T. Aggarwal and K. Pankaj, "PopulationUrbanization-Energy Nexus: A Review," Faculty of Environmental Earth Science, Hokkaido University, Sapporo 060-0810, Japan: Resources 8,136,30 July, 2019.

[2] B. Adebanji, O. Atoki, T. Fasina, A. Abe and O. Adetan, "Comparative study of off-grid and grid-connected hybrid power system: issues, future prospects and policy framework" Indonesian Journal of Electrical Engineering and Computer Science (IJEECS), Vol. 22, issue 2, pp. 144-151, 2021.

[3] B. Adebanji, Development of a hybrid power system model for rura electrification, unpublished $\mathrm{Ph}$. D thesis submitted to the Departmen of Electronic and Electrical Engineering, Ladoke Akintola University of Technology, Ogbomoso, Nigeria (2019).

[4] S. O. Oyedepo, "Energy and sustainable development in Nigeria: the way forward," Energy, Sustainability and Society, 2012, 2:15.

[5] B. Adebanji, G.A.Adepoju, J. O. Ojo, and P.K. Olulope, "Optimal Sizing of an Independent Hybrid Small Hydro-Photovoltaic-BatteryDiesel Generator Hybrid Power System for a Distant Village," International Journal of Scientific and Technology Research, 2017, vol. $6(8)$, pp. 208-213.

[6] T.Fasina, B. Adebanji, A.Abe, and I. Ismail, "Impact of distributed generation on Nigerian power network," International Journal of Electrical Engineering and Computer Science, IJEECS, 2021, vol. 9 (4), pp. 304-3050.

[7] B. Adebanji, G.A.Adepoju, P.K.Olulope, E.T. Fasina, and O. Adetan "Feasibility and Optimal Design of a Hybrid Power System for Rural Electrification for a Small village in Nigeria," International Journal of Electrical and Computer Engineering, vol. 10, pp. 6214-6224, 2020.

[8] G. Dolf, B. Francisco, S. Deger, D. B. Morgan, W. Nicholas, G. Ricardo, "The role of renewable energy in the global energy transformation," International Renewable Energy Agency (IRENA), Energy strategy reviews, pp. 2430-50, 2019.01.006.

[9] G.A. Adepoju, and B. Adebanji, "Feasibility and Optimal Design of Small Hydropower-Solar- Photovoltaic-Diesel-Generator Hybrid Power System for Itapaji-Ekiti state, Nigeria," Science Domain International, Journal of Scientific Research and Reports, vol. 11(2), pp. 1-10, 2016

[10] M. S. Adaramola and M.S. Oyewola, "Evaluating the performance of wind turbines in selected locations in Oyo state, Nigeria," Journal of Renewable Energy, vol. 36, pp. 8-15, 2011

[11] B. Akuru, U and O. I. Okoro, "Renewable energy investment in Nigeria: A review of the Renewable Energy Master Plan," Journal of Energy in Southern Africa, vol. 25(3), pp. 67-73, 2011

[12] K.J. Kumar and M.S. Kalavathi, "Optimal sizing of grid-connected hybrid PV/wind/battery power system using Satin Bowerbird optimization," International Journal of Innovative Technology and Exploring Engineering, vol. 8(4), 2019.

[13] O.D. Atoki, B.Adebanji, A.Adegbemile, E.T. Fasina, and O.D Akindele, "Sustainable Energy Growth in Nigeria: The role of Grid- connected hybrid power system," International Journal of Scientific and Technology Research, vol. 9 (9), pp. 274-281, 2020.

[14] M. B. Olubayo, S. A. Oluwaseye, E. B. Damilola and H. D. Iheanacho, "Grid Hybrid Renewable System for Rural Healthcare centre: A case Study in Nigeria," Energy Science \&Engineering, published by the Society of Chemical Industry and John Wiley \& Sons Ltd Energy Sci Eng. Vol. 7, pp. 676-693, 2019.

[15] A. B. Esan, A. F. Agbetuyi, O. K. Ogboreda, A. A. Ogbeide, A. A Awelewa and B. Afolabi, "Reliability assessments of an islanded hybrid pv-diesel battery system for a typical rural community in Nigeria", Heliyon, 1-13.

[16] M. Usman, M. T. Khan and A.S. Ali, "Techno-economic analysis of hybrid solar-diesel-grid connected power generation system," Journal of Electrical Systems and Information Technology, vol. 5, pp. 653-662, 2018.

[17] M. Fadaeenejad, M. Radzi, M. Z. A. Abkadir and H. Hizam, "Assessment of Hybrid Renewable Power Sources for rural Electrification in Malaysia," Renewable and sustainable Energy. Review, vol. 30, pp. 299-305, 2014

[18] T. Nigussie, W. Bogale, F. Bekele and Dribssa, "Feasibility study for power generation using off-grid energy system from micro hydro-PV diesel generator-battery for rural area of Ethiopia: The case of Melkey Hera village, Western Ethiopia," AIMS Energy, vol. 5(4), pp. 667-690, 2017.

[19] S. S.Mendu, P. Applikanda, A. K. Emadabathumi and N. Koritala "Techno-economic comparative analysis between grid-connected and stand-alone integrated energy systems for an educational institute," Evergreen Joint Journal of Novel Carbon Resource Sciences and Green Asia Strategy, vol. 7(3), pp. 382-395, 2020.

[20] O. I. Faleyimu, B. O.Agbeja, and O.Akinyemi, "State of forest regeneration in Southwest Nigeria," African Journal of Agricultural Research, Vol. 8(26), pp. 3381- 3383, ISSN 1991-637X, 2013.

[21] O. F. Olakunle, A. Omotayo and S. G. Odewumi, "Pattern and problems of deforestation in south-western Nigeria," International Journal of Academic Research, vol. 3, pp. 641-655, 2011

[22] H. Makinde (August2018). Distributional Pattern of the Petrol Filling Stations in Ibadan [Online]. Available: https://www.academia.edu/40746656/Makinde.

[23] (NCC 2019). Retrieved from National Control Centre (NCC) Osogbo, Osun state.

[24] Ogun-Osun River Basin Development Authority (OGOSRBDA) (2019). Hydro Data. Retrieved from Osun River Basin Developmen Authority (OGOSRBDA). Plot 22, Alabata Road, Abeokuta, Abeokuta North,

Ogun, Nigeria:http//www.manpower.com.ng/company/871/ogun-osun-riverbasin-development authority

[25] National Aeronautic Space Administration (October 2019) [Online]Available:https://power.larc.nasa.gov/cgibin/v1/DaAccess.py ?\&request=execute identifier $=$ Single Point \& parameters= ALLSKY SFC SW DWN\&startDate=2009\&endDate=2018\&userC 
ommunity $=$ SSE $\&$ tempAverage $=$ INTERANNUAL\&outputList $=$ ASCI I\&lat=7.9525\&lon $=5.465$.

[26] L. K. Deepak, D. BibhutiBhusan and Akella, "Optimization of PV/Wind/Micro-Hydro/Diesel Hybrid Power System in HOMER for the Study Area," International Journal on Electrical Engineering and Informatics, vol. 3.3, pp. 307-325, 2011.

[27] A. Vahabzadeh, F. Separi, M. Samkush, M. Jafari, Optimal Sizing of Hybrid Energy resources for Electricity of Distant Rural areas of Iran, Paper no. 03222 CIRD Workshop- Lisbon, 2012, pp. 29-30.

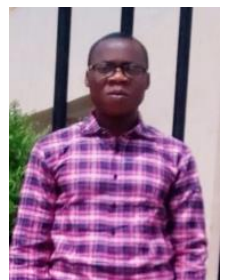

Ajeba S. Wilfred was born in Ibore-Irrua, Edo state, Nigeria. He received his B. Eng Degree in Electrical and electronic Engineering from Ambrose Alli University, Edo State in 2001.

$\mathrm{He}$ is currently an employee of Ajaokuta Steel Company, Ajaokuta, Kogi State, Nigeria as Assistant General Manager, and a Master degree student of Ekiti State University, Edo-Ekiti, Nigeria.

Engr. Ajeba is registered with Council for the Regulation of Engineering in Nigeria (COREN) and also a member of the Nigerian Society of Engineers (NSE). His research interests are renewable energy technologies and power system control.

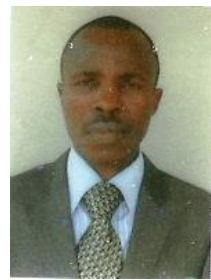

Bankole Adebanji received his B. Eng. degree in Electrical and Electronic Engineering in 1997 from the then Ondo State University, Ado-Ekiti, Ekiti State, Nigeria (now Ekiti State University, Ado-Ekiti), M Tech. degree (Electronic and Electrical Engineering) and $\mathrm{Ph} . \mathrm{D}$ degree (Power System Engineering and Machine) from Ladoke Akintola University of Technology (LAUTECH), Ogbomoso, Nigeria in 2010 and 2019 respectively.He is currently lecturing in the Electrical and Electronic Engineering department of Ekiti State University, Ado-Ekiti, Nigeria.He is a resgistered COREN Engineer and a member of Nigerian Society of Engineers (MNSE). His researh interest are Renewable energy,Power system engineering,Hybrid, Small hydro and optimization.

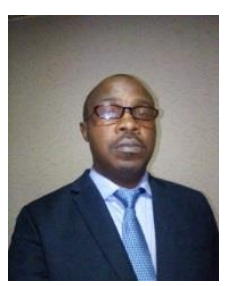

Taiwo Fasina received B. Eng. degree in Electrical and Electronic Engineering from Ondo State University Ado Ekiti, Nigeria in 1998 and M. Tech. degree in Electronic and Electrical engineering from Ladoke Akintola University of Technology, Ogbomoso, Nigeria in 2012. He completed his Ph.D. in Electrical and Electronic Engineering from Cardiff University, UK in 2019. He is a registered member of the Council for the Regulation of Engineering in Nigeria (COREN) and the Nigeria Society of Engineers (NSE). He is currently a lecturer in Ekiti State University, Ado Ekiti Nigeria. His main interest includes power system analysis and control, Integration of distributed generation, storage, and electric vehicle into the grid, localised energy systems, deregulation, and electricity transmission pricing. 